ISSN: 1829-6750 Inovasi Kurikulum, Februari 2009, Thn. 6. Vol 6 Nomor: 1

\title{
PENYEMPURNAAN KURIKULUM MADRASAH DALAM KONTEKS KTSP
}

\section{Aceng Abdul Azis}

Abstrak: Pengembangan kurikulum harus segera dilakukan, selain merespons perubahan paradigmatik pendidikan, juga mengantisipasi terjadinya perubahan strategis bidang sosial, budaya, ekonomi dan politik. Kurikulum Tingkat Satuan Pendidikan (KTSP), secara konseptual mempunyai semangat global, nasional dan lokal sekaligus. Bahkan, KTSP menjadi petanda bagi revitalisasi sekolah/madrasah dalam menciptakan pembelajaran yang relevan dengan perubahan sosial. Jika setiap madrasah/sekolah mampu mendisain sebuah KTSP, maka akan didapati variasi KTSP sejumlah madrasah/sekolah tersebut.

Penelitian yang dilakukan di MTs Darul Muttaqin menunjukkan adanya ekuivalensi antara "kurikulum yang asli" dengan kurikulum tingkat satuan pendidikan yang sedang dirumuskannya. Dalam konsepsi kurikulum Tarbiyatul Mu'allimin wal Mu'allimat al Islamiyyah (TMI), madrasah ini mempunyai identitas lokalnya, karakter internalnya dan cita-cita khususnya.

Perilaku KBM di madrasah ini, hingga saat ini masih mengimplementasikan kurikulum TMI yang dirumuskannya sendiri. Namun demikian, relasi MTs Darul Muttaqin dengan madrasah lain, dengan birokrasi pendidikan, dan dengan stakeholders memberikan perspektif baru tentang perlunya KTSP. Kepala MTs Darul Muttaqin menganggap adopsi dokumen KTSP perlu dilakukan agar perilaku mengajar berubah seiring dengan perubahan dokumen kurikulum, sehingga mutu madrasah meningkat seirama dengan dinamika pendidikan pada umumnya.

Kata Kunci: Kurikulum Madrasah, KTSP 
ISSN: 1829-6750 Inovasi Kurikulum, Februari 2009, Thn. 6. Vol 6 Nomor: 1

\section{A. Pendahuluan}

Sampai saat ini pertumbuhan madrasah tidak seiring dengan kesadaran para pendirinya untuk meningkatkan mutu madrasah dalam pengertian luas yang meliputi aspek manajemen, kurikulum, SDM, net-working, dan partisipasi masyarakat. Akhirnya, masih dijumpai realitas yang memprihatinkan dalam tahun "reformasi pendidikan", yakni adanya $85,7 \%$ dari total madrasah swasta (sebanyak 39.309 lembaga) menyandang predikat "tidak mampu" atau sulit berkembang karena penyokong utamanya adalah masyarakat yang kemampuan ekonominya rendah (Depag RI, 2003: 2).

Kondisi madrasah swasta pada umumnya membutuhkan perhatian, penanganan dan perawatan secara ekstra keras. Perlakuan khusus yang ditawarkan pemerintah, selain untuk madrasah negeri (dari total jumlah madrasah yang negeri 8,4 $\%$ ), diperkirakan baru menyentuh sekitar $10 \%$ madrasah swasta yang tersebar di seluruh tanah air. Dalam rangka mengatasi problem tersebut, partisipasi masyarakat dalam menjaga eksistensi madrasah perlu ditingkatkan. Jika saat ini, realitas madrasah tertinggal dari sekolah salah satu sebabnya adalah gap antara madrasah dan masyarakat itu sendiri, yang tidak menyokongnya. Disinilah perlu revitalisasi hubungan antara madrasah dengan masyarakat.

Dalam konteks demikian, Kurikulum Tingkat Satuan Pendidikan (KTSP), yang merupakan derivasi teoritis dari konsep school based curriculum sebagaimana di Amerika dan Australia (Print, 1993: 20), mempunyai signifikansi korelasional dengan kinerja madrasah swasta yang mengusung social support dalam proses pembelajaran. Pengembangan kurikulum membutuhkan pola yang adaptif dengan denyut sosial dalam multidimensinya, yang demokratis, tidak robotis, dan memiliki pola yang bertitik tolak dari permasalahan dan tantangan dalam kehidupan senyatanya. (Hamalik, 2000: 60).

Kurikulum Tingkat Satuan Pendidikan (KTSP) yang modelnya dikenalkan BSNP setelah terbitnya PP No. 19 Tahun 2005, secara konseptual dapat menjadi kurikulum ideal yang mempunyai 
ISSN: 1829-6750 Inovasi Kurikulum, Februari 2009, Thn. 6. Vol 6 Nomor: 1

semangat global, nasional dan lokal sekaligus. Bahkan, KTSP menjadi petanda bagi revitalisasi institusi sekolah/madrasah beserta stakeholdersnya dalam mendorong terciptanya pembelajaran yang relevan dengan derap langkah perubahan sosial.

Peneliti akan mencoba mencatat proses perubahan yang terjadi dalam pengembangan KTSP secara deskriptif. Bagaimana proses kinerjanya, keterlibatan para guru dan staf, perubahan komponen kurikulum, persepsi para pengembangan terhadap perubahan dokumen kurikulum dan bagaimana rancangan implementasinya. Peneliti mencoba melihat dari dalam (inward looking) tentang perubahan yang dilakukan, karena peneliti sendiri terlibat dalam lingkungan tersebut. Melalui pendekatan kualitatif, peneliti berusaha keras untuk dapat menggambarkan apa yang sedang berjalan dan apa dampak dari tindakan penelitian yang dilakukan secara simultan tersebut.

Berdasarkan survey awal, ditemukan dua kesan penting. Pertama, para penanggung jawab dan para penyelenggara pendidikan di lingkungan Pondok Pesantren Darul Muttaqin Bogor sangat terbuka terhadap berbagai isu, informasi dan kebijakan pendidikan baru. Kedua, perumusan kebijakan pendidikan Darul Muttaqin tampaknya senantiasa mempertimbangkan keaslian (authentically) sebagai pesantren yang mempunyai ciri khas sebagai lembaga pendidikan Islam yang memelihara fungsi tafaqquh fiddin.

Berkaitan dengan proses adaptasi kurikulum tersebut, peneliti mencoba menangkap adanya "skenario gerhana" empat tahap di bawah ini, yang menggambarkan proses adaptasi terhadap inovasi kurikulum yang dilakukan pada MTs Darul Muttaqin.

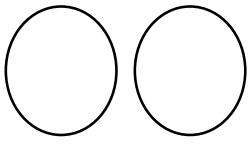

1

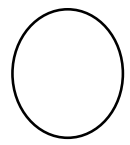

4

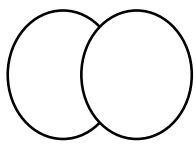

2

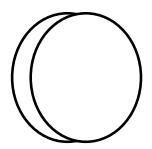

3
Gambar-1Adaptasi Kurikulum 
ISSN: 1829-6750 Inovasi Kurikulum, Februari 2009, Thn. 6. Vol 6 Nomor: 1

Peneliti mendapatkan kesan kuat bahwa MTs Darul Muttaqin mempertahankan TMI-nya, tetapi menerima tawaran perubuhan kurikulum dari pihak luar (eksternal). Dalam perspektif model adaptasi kurikulum di atas, tampaknya MTs Darul Muttaqin ada pada posisi kedua yang saling menunjukan dominasinya sehingga memberikan ranah arsir yang hanya sekitar $20 \%$. Dengan kata lain, pembelajaran pada MTs Darul Muttaqin memberikan muatan agama yang lebih besar porsinya jika dibandingkan dengan MTs lainnya. Di mana MTs yang lain mengadaptasi total KTSP versi SI SKL Pendidikan Agama Islam dan Bahasa Arab berdasarkan Permenag No. 2 Tahun 2008.

Diharapkan penelitian ini dapat mempertemuakan kebutuhan anak didik, harapan orang tual masyarakat dan tugas madrasah dalam mengembangkan ilmu pengetahuan dan teknologi. Berdasarkan uraian di atas, peneliti ingin lebih fokus pada beberaba masalah pengembangan kurikulum, sebagai berikut: (1) Mengenai kurikulum Tarbiyatul Mu'allimin wal Mu'allimat al-Islamiyyah (TMI) yang digunakan MTs Darul Muttaqin; (2)
Mengenai proses pengembangan KTSP pada MTs Darul Muttaqin dan keterlibatan tenaga pendidik/ kependidikan serta pihak-pihak berkepentingan dalam pengembangan kurikulum tersebut; dan (3) Mengenai komponen-komponen kurikulum (tujuan, isi, pengorganisasian, proses dan evaluasi) yang diharapkan.

\section{B. KAJIAN PUSTAKA}

\section{Kurikulum Tingkat Satuan Pendidikan}

Kurikulum Tingkat Satuan Pendidikan (KTSP) adalah kurikulum operasional yang disusun oleh dan dilaksanakan di masingmasing satuan pendidikan. Penyusunan operasional pembelajaran tersebut dilaksana-kan secara kolektif antara kepala sekolah/madrasah, guru dan komite sekolah/madrasah sesuai dengan prosedur yang dikeluarkan oleh Badan Standar Nasional Pendidikan (BSNP). Pengembangan KTSP disesuaikan dengan satuan pendidikan, potensi daerah, karakteristik daerah, sosial budaya masyarakat setempat dan peserta didik. 
ISSN: 1829-6750 Inovasi Kurikulum, Februari 2009, Thn. 6. Vol 6 Nomor: 1

Kurikulum 2006 merupakan hasil penyempurnaan Kurikulum 2004 yang wujudnya bisa dilihat dalam konseptualisasi Stándar Kompetensi dan Komptensi Dasar (SKKD). Kurikulum ini telah disahkan penggunaannya di sekolah/ madrasah secara berangsur-angsur mulai tahun ajaran 2006/2007, baik jenjang pendidikan dasar maupun jenjang pendidikan menengah.

Bagi sekolah/madrasah yang belum siap, bisa melanjutkan penggunaan kurikulum yang sedang mereka gunakan saat ini (Mulyasa, 2006: 1). Oleh karena itu, bisa jadi saat ini di sekolah/madrasah terjadi tiga macam penggunaan kurikulum: Kurikulum 1994, Kurikulum 2004 dan Kurikulum 2006. Pemerintah memang menyediakan waktu yang cukup longgar untuk implementasi Kurikulum 2006, yakni hingga tiga tahun ajaran kedepan, sehingga diperkirakan pada tahun ajaran 2009/2010 semuanya sudah melaksanakan. Hal ini sesuai dengan Peraturan Mendiknas RI Nomor 24 Tahun 2006 tentang Pelaksanaan Permen No. 22 Tahun 2006 tentang Standar Isi dan Permen No. 23 Tahun 2006 tentang SKL untuk Pendidikan Dasar dan Menengah.

\section{Pengembangan Kurikulum di Madrasah}

Banyak momentum penting dalam konteks pemberdayaan pendidikan agama di Indonesia, antara lain dibentuknya Departemen Agama tahun 1946, dimuat tentang pendidikan madrasah dalam UU No. 4 Tahun 1950 yang menyetarakan posisi madrasah dan sekolah dalam konteks wajib belajar. Tahun 1958 dikenalkan istilah Madrasah Wajib Belajar (7-8 tahun), tahun 1975 diterbitkannya SKB 3 Menteri yang ditindaklanjuti dengan disusunnya kurikulum tahun 1975 yang membagi $70 \%$ umum $30 \%$ agama. Tahun 1990 predikat madrasah menjadi sekolah yang berciri khas agama Islam, pembaharuan kurikulum tahun 1994 dan 1998 yang tetap mengakomodasi ciri khas agama Islam, serta tahun 2003 yang eksplisit dalam UU Nomor 20 Tahun 2003 tentang Sistem Pendidikan Nasional, tidak ada lagi diskriminasi antara madrasah dan sekolah.

Madrasah adalah lembaga pendidikan Islam jenjang pendidikan tingkat dasar (MI dan MTs) dan menengah (MA dan MAK) yang diselenggarakan secara formal 
ISSN: 1829-6750 Inovasi Kurikulum, Februari 2009, Thn. 6. Vol 6 Nomor: 1

sesuai dengan undang-undang dan peraturan yang berlaku yang memberi tekanan pada ciri khas keislaman melalui tafaqquh fi aldiin, pembudayaan akhlakul karimah dan pembentukan tamaddun Islam.

Pendidikan Islam mengajarkan bahwa proses pendidikan seharusnya tidak hanya diorientasikan pada transformasi ilmu pengetahuan, akan tetapi merupakan proses pembinaan, pengembangan dan pembentukan karakter anak didik. Di sini sesungguhnya madrasah memainkan peran yang sangat vital terhadap penyiapan generasi bangsa yang 'alim 'amaly dan 'a-mil 'ilmy memiliki integritas il-miyah dan amaliyah sekaligus.

Oreintasi pendidikan Islam tersebut secara khusus juga membawa perubahan penting keberadaan pendidikan agama dan pendidikan agama dan keagamaan yang selama ini menjadi tanggung jawab Depertemen Agama. Posisi sekolah umum dan madrasah, kini benarbenar sejajar; sedangkan pendidikan keagamaan di sektorsektor non formal mendapatkan pengakuan resmi sebagai bagian dari sistem pendidikan nasional, sebagaimana diatur dalam Peraturan Pemerintah No 55 Tahun 2007.

Konsekwensi dari perubahan paradigma pendidikan tersebut adalah munculnya berbagai spekulasi baru dalam proses pembelajaran. Masyarakat pendidikan kini mulai terbuka dengan berbagai model pembelajaran "baru" yang mulai menempatkan siswa sebagai titik utama, atau proses sebagai sesuatu yang lebih penting daripada proses, dan sebagainya. Salah satu pendekatan yang akhir-akhir ini menjadi bahan kajian pada umumnya praktisi pendidikan adalah implementasi KTSP.

Dalam rangka meningkatkan mutu isi dan proses pendidikan madrasah, berikut ini beberapa langkah yang dapat dilakukan, antara lain: Melibatkan Komite Madrasah dan Stakeholders, Meningkatkan Kemandirian Madrasah, dan Menciptakan Lingkungan Madrasah yang Kondusif.

\section{Proses Pengembangan Kurikulum}

Secara luas, kurikulum dipahami sebagai seluruh pengalaman belajar yang direncanakan/ 
ISSN: 1829-6750 Inovasi Kurikulum, Februari 2009, Thn. 6. Vol 6 Nomor: 1

ditawarkan/diarahkan oleh lembaga pendidikan dan bahkan meliputi pengalaman yang tidak direncanakan (hidden curriculum), untuk mencapai serangkaian tujuan (a structured series of intended learning outcomes). Dalam prakteknya, kurikulum terbagi menjadi dua jenis: (1) curriculum document (inner curriculum), dan (2) operative curriculum (fungtioning, live). (Zais, 1976: 11).

Di kawasan manapun, di era kapanpun, kurikulum memegang kedudukan kunci dalam pendidikan, sebab berkaitan dengan penentuan arah, isi dan proses pendidikan, yang pada akhirnya menentukan performa dan kualifikasi lulusan suatu lembaga pendidikan. Kurikulum tersebut menyangkut rencana dan pelaksanaan pendidikan baik dalam lingkup kelas, sekolah/madrasah, daerah, wilayah maupun nasional. (Sukmadinata, 2005: v).

Hamalik (2000) menyebutkan sedikitnya terdapat 25 model pengembangan kurikulum yang terdiri dari 16 buah model kerangka kerja (frame-work) kurikulum, 5 buah model segmen kurikulum yakni desain sistem instruksional, dan 3 buah model segmen kurikulum desain sistem pelatihan, serta 1 buah model perencanaan program. Menurutnya, setiap kali ada permintaan untuk mengembangkan suatu kurikulum senantiasa diawali dengan pertanyaan, model kurikulum apa yang hendak disusun atau dikembangkan? Oleh karena itu, mengenal model-model pengembangan kurikulum sangat diperlukan bagi tenaga kependidikan umumnya dan tenaga pengembang kurikulum pada khususnya.

Terdapat empat faktor yang memberikan landasan dalam pengembangan kurikulum, yaitu landasan filosofis, landasan psikologis, landasan sosial-budaya, dan landasan ilmu pengetahuan dan teknologi. Keempatnya memberikan pengaruh yang berbeda-beda terhadap komponen kurikulum yang meliputi tujuan pendidikan, isi pendidikan, proses pendidikan dan evaluasi.

Selain keempat landasan pengembangan kurikulum tersebut, sering tambahkan pula landasan organisatoris (Nasution, 2003: 176; Abdullah Idi, 2007: 92). Dengan landasan organisatoris, pengembang kurikulum (curriculum developers) mengorganisasikan 
ISSN: 1829-6750 Inovasi Kurikulum, Februari 2009, Thn. 6. Vol 6 Nomor: 1

bahan pembelajaran berdasarkan tujuan dan sasarannya, juga berdasarkan topik, konsep, logika, kronologi, dan sebagainya.

Dengan demikian, landasan pengembangan kurikulum sangat diperlukan agar beberapa komponen kurikulum bisa menjadi sistem yang saling mendukung terhadap pencapaian tujuan pembelajaran.

Menurut Sukmadinata (2005: 150), dalam pengembangan kurikulum hendaknya memperhatikan prinsipprinsip umum, yaitu: relevansi, prinsip fleksibilitas, prinsip kontinuitas, prinsip praktis, dan prinsip efektifitas. Dijelaskan Idi (2007: 179-183), prinsip relevansi meliputi: (1) relevansi pendidikan dengan lingkungan anak didik, (2) relevansi pendidikan dengan kehidupan yang akan datang, (3) relevansi pendidikan dengan dunia kerja, (4) relevansi pendidikan dengan ilmu pengetahuan. Prinsip fleksibilitas meliputi: (1) fleksibilitas dalam memilih program pendidikan, dan (2) fleksibiltas dalam pengembangan program pengajaran. Prinsip kontinuitas dalam pengembangan kurikulum menunjukkan adanya saling terkait antara tingkat pendidikan, jenis program pendidikan, dan bidang studi.

\section{METODE PENELITIAN}

Dalam penelitian ini, penulis menggunakan metoda penelitian deskriptif, sebuah metoda untuk tujuan mendeskripsikan atau menggambarkan fenomenafenomena yang ada, baik fenomena yang bersifat alamiyah maupun fenomena hasil rekayasa. Best, John W. (Sukmadinata, 2005: 74) bahwa penelitain deskriptif tidak hanya berhenti pada pengumpulan data, pengorganisasian, analisis dan penarikan interpretasi serta penyimpulan, tetapi dilanjutkan dengan pembandingan, mencari kesamaan-perbedaan dan hubungan kausal dalam berbagai hal. Penemuan makna adalah fokus dari keseluruhan proses yang dilakukan.

D. HASIL DAN PEMBAHASAN

1. Kurikulum TMI Mempunyai Landasan, Struktur dan Komponen yang Relevan untuk Penyusunan dan Pengembangan KTSP MTs Darul Muttaqien 
ISSN: 1829-6750 Inovasi Kurikulum, Februari 2009, Thn. 6. Vol 6 Nomor: 1

Pendidikan di MTs Darul Muttaqien mendasarkan pemahaman analogis Gagne (1977) yang mengatakan bahwa belajar diibaratkan sebagai proses membangun sebuah gedung. Siswa secara terus menerus membangun makna baru (pengetahuan, sikap dan keterampilan) berdasarkan apa yang telah mereka kuasai sebelumnya. Sifat terus menerus (long life education) yang dilekatkan dalam proses belajar siswa di MTs Darul Muttaqien didasarkan oleh pesan Rasulullah dalam sebuah hadist yang mengatakan bahwa menuntut ilmu itu dari buaian hingga liang lahat. Karenanya kurikulum yang dikembangkan di MTs Darul Muttaqien tidak hanya kurikulum yang bersifat tertulis dokumentatif. Oleh karenanya bagi MTs Darul Muttaqien perubahan kurikulum ini tidak hanya sebatas perubahan kurikulum sebagai dokumen namun juga mesti berimplikasi pada perubahan perilaku guru.

Keputusan mengembangkan kurikulum TMI di MTs Darul Muttaqin sebenarnya menjadikan madrasah memiliki full authority and responsibility dalam menetapkan program-program pendidikan dan berbagai kebijakan sesuai dengan visi, misi, dan tujuan pendidikan, sehingga madrasah mengembangkan berbagai program pembelajaran sesuai dengan kebutuhan, ciri khas dan tuntutan perkembangan masyarakat. Namun para pengembang kurikulum dalam merancang dan menyusun struktur dan muatan kurikulum TMI di MTs Darul Muttaqien masih memadukan muatan-muatan kurikulum nasional baik yang dikembangkan oleh Diknas maupun Depag. Sehingga adanya pengadaptasian mengenai struktur dan muatan kurikulumnya.

Mendesain kurikulum TMI MTs Darul Muttaqien para pengembang kurikulum mendasarkan pada visi dan misi pendidikan nasional dengan lebih menekankan pada tujuan pendidikan madrasah dengan ciri khasnya yang Islami, serta tidak bertentangan dengan tujuan pendidikan tingkat dasar. Adapun pertautan antara kelompok elemen atau unsur lintas tingkatan sekolah, yakni MTs dengan MA merupakan bentuk artikulasi horizontal. Oliva (1992: 524) menjelaskan bahwa artikulasi sangat erat hubungannya dengan sekuens dan kontiutas.

Pelaksanaanya, kegiatan pengembangan diri terbagi menjadi tiga 
ISSN: 1829-6750 Inovasi Kurikulum, Februari 2009, Thn. 6. Vol 6 Nomor: 1

bagian. Pertama, kegiatan pengembangan diri diberikan diluar jam pelajaran (ekstrakulikuler) dibina oleh guru-guru yang memiliki kualifikasi yang baik berdasarkan surat keputusan kepala sekolah. Kedua, alokasi waktu ekuivalen dengan jam pelajaran dilaksanakan setiap hari setelah jam pelajaran efektif selesai. Ketiga, penilaian kegiatan pengembangan diri harus dilakukan secara berkala dan dilaporkan kepada kepala sekolah dan orang tua dalam bentuk kualitatif, bukan kuantitatif.

\section{Proses Pengembangan KTSP MTs Darul Muttaqien Merupakan Adaptasi Formal- Dokumenter pada Aspek Pedoman Pembelejaran}

Filosofi perumusan KTSP MTs Darul Muttaqien dan aplikasinya pada peserta didik dalam proses belajar dilakukan melalui tiga cara, yaitu pengalaman (dengan kegiatan langsung atau tidak langsung), pengamatan (melihat contoh atau model) dan melalui bahasa. Mereka menggali, melakukan, menguji coba, menemukan, mengungkap-kan, dan membangun secara aktif pengetahuan yang baru melalui konteks yang otentik. Ini berarti, kegiatan belajar melalui apa yang dilakukan secara aktif oleh siswa. Ini berarti, sesibuk apapun yang dilakukan guru, namun jika siswa tidak belajar, maka sebenarnya proses pembelajaran tidak terjadi. Hal ini disadari betul oleh kepala madrasah dan guru MTs Darul Muttaqien.

Kurikulum dokumen MTs Darul Muttaqin adalah TMI, sebagamana sudah dikemukan di muka. Dari segi konten kurikulum, perencanaan pembelajaran, pemilihan sumber belajar, penggunaan metoda mengajar, penentuan alat evaluasi, pelaporan pendidikan, komunikasi dua arah dengan komite atau orang tua murid, dan lain-lain, sudah dilaksanakan relatif memadai. Bahkan, status akreditasi MTs Darul Muttaqin mencapai derajat $A$, nilai tertinggi jika dilihat dari terpenuhinya aspek-aspek pendidikan madrasah yang ideal. Oleh karena itu, KTSP yang akan dirancang oleh MTs Darul Muttaqin ini sudah mempunyai modal dasar yang cukup positif dalam pengembangan KTSP.

MTs Darul Muttaqin telah meletakkan landasan kurikulum yang tepat dan selalu merespons setiap erjadi perubahan isu 
ISSN: 1829-6750 Inovasi Kurikulum, Februari 2009, Thn. 6. Vol 6 Nomor: 1

pembelajaran. Para guru di sini mengatakan bahwa setelah KTSP dikenalkan tahun 2006, MTs Darul Muttaqin masih melanjutkan penggunaan KBK. Tentu saja hal ini tepat, karena dari segi konten kurikulum baru ini tetap berbasis kompetensi. Perbedaanya adalah KBK berlaku secara nasional, sementara KTSP ingin menempatkan setiap keunikan satuan pendidikan sebagai modal dasar pengembangan kurikulum, dengan harapan akan terjadi proses belajar mengajar yang lebih efektif dan efisien.

Keunikan rancangan KTSP di MTs Darul Muttaqien sesungguhnya didasarkan pada kondisi lingkungan belajar siswa yang unik pula. Penggabungan antara teori yang diberikan di kelas dengan praktek langsung dalam kehidupan seharihari menjadi paket pendidikan dan pengajaran dengan sistem pendampingan, bimbingan dan pengarahan langsung olah guru selama 24 jam. Dengan kata lain proses hidup siswa terpantau guru mulai dari bangun tidur sampai mau tidur lagi. Evaluasi yang sering munculpun dikaitkan dengan kesesuaian materi yang diberikan oleh guru di sekolah dengan perilaku sehari-hari di pesantren.
Melihat kondisi ini sesungguhnya filosofi KTSP sebenarnya telah melekat dalam proses pendidikan dan pengajaran di MTs Darul Muttaqien. Tinggal bagaimana mendokumentasikan aplikasi ini dalam bentuk kurikulum tertulis berdasarkan kaidah-kaidah yang telah ditetapkan oleh pemerintah.

Proses pengembangan KTSP di MTs Darul Muttaqien dengan menggunakan pola adaptif ini menurut Hamalik (2000: 60) bertitiktolak dari permasalahan dan tantangan dalam kehidupan nyata. Dengan berpedoman pada prinsipprinsip pengembangan kurikulum oleh Peraturan Menteri Pendidikan Nasional Nomor 22 tahun 2006, yaitu: a) Berpusat pada potensi, perkem-bangan, kebutuhan dan kepentingan peserta didik dan lingkungannya. b) Beragam dan terpadu. c) Tanggap terhadap perkembangan ilmu pengetahuan, teknologi dan seni. d) Relevan dengan kebutuhan kehidupan.e) Menyeluruh dan berkesinambungan. f) Belajar sepanjang hayat dan g) Seimbang antara kepentingan nasional dan kepentingan daerah.

Proses di atas sebenarnya merupakan derivasi teoritis dari konsep school based curriculum 
ISSN: 1829-6750 Inovasi Kurikulum, Februari 2009, Thn. 6. Vol 6 Nomor: 1

yang dikembangkan di Amerika dan Australia yang menurut Print (1993: 20) mempunyai signifikansi korelasional dengan kinerja pembelajaran.

\section{Para Guru Memberikan Kontribusi Paling Signifikan dalam Pengembangan KTSP MTs Darul Muttaqin}

Pengembangan KTSP MTs Darul Muttaqin mencoba melibatkan unsur pengembang yang beragam, mulai para administrator pendidikan, para ahli dan para orang tua murid. Komite madrasah didekati untuk ikut memberikan masukan dalam perumusan KTSP dengan berbagai cara, terutama dalam pertemuan kedua belah pihak secara resmi. Akan tetapi, pada prakteknya peranan guru sangat dominan, karena merekalah yang telah melaksanakan ide-ide spesifik yang menjadi ciri khas lembaga pendidikan Darul Muttaqin untuk dapat tercapai bersamasama dalam proses pembelajaran.

Terjadi kondisi yang mirip dengan kesimpulan masyaakat pendidikan selama ini, bahwa gurulah yang memegang peranan yang penting baik dalam perencanaan maupun pelaksanaan kurikulum. Mereka adalah perencana, pelaksana, dan pengembang kurikulum bagi kelasnya. (Sukmadinata, 2004: 157).

Optimalisasi peran guru dalam pengembangan kurikulum ternyata belum seimbang dengan kenyataan kapasitas dan kompetensi mereka dalam bidang ini. Berbeda dengan kurikulum masa lalu, guru dapat menjadi penerjemah kurikulum pusat. Ketika itu, pengembangan kurikulum lebih merupakan aktifitas "pengolahan bahan belajar yang disesuaikan dengan tuntutan kelas". Jauh berbeda dengan KTSP, yang mana pengembangan kurikulum ini membutuhkan sejumlah keahlian khusus. Sementara itu, MTs Darul Muttaqin hanya memiliki 60 persen yang kualifikasi sarjana pendidikan.

3. Komponen-komponen Kuriku-lum TMI Memperkuat Substan-si, Arah dan Tujuan Pembelajaran yang Dirumuskan dalam Kurikulum Tingkat Satuan Pen-didikan (KTSP) MTs Darul Mutta-qien

Dalam proses pengembangan KTSP, para pengembang kurikulum MTs Darul Muttaqin mengurai komponen-komponen tersebut 
ISSN: 1829-6750 Inovasi Kurikulum, Februari 2009, Thn. 6. Vol 6 Nomor: 1

dalam rangkaian visi, misi, dan tujuan; serta struktur, muatan dan evaluasinya.

a. Visi Madrasah

Visi madrasah yang dikembangkan dalam KTSP MTs Darul Muttaqien adalah "Terwujudnya madrasah yang Islami dan unggul dalam menyiapkan generasi muslim berdasarkan Iptek dan Imtaq".

b. Misi Madrasah

Misi yang dikembangkan dalam KTSP MTs Darul Muttaqin adalah sebagai berikut: a) Menerapkan manajemen berbasis madrasah (MBS), b) Menerapkan pembelajaran yang efektif dan menyenangkan bagi guru dan siswa, c) Meningkatkan kemampuan berbahasa Arab dan Inggris, d) Meningkatkan penghayatan dan pengalaman ajaran Islam, e) Meningkatkan motivasi belajar dan prestasi siswa, dan f) Mengembangkan intelektualitas dan spiritualitas siswa.

C. Tujuan

Madrasah Darul Muttaqin mempunyai 4 tujuan utama yaitu; a) Menanamkan aqidah shohihah dan akhlaq karimah, b) Meningkatkan intelektualitas, c) Membentuk sikap mandiri, dan d) Mengembangkan keterampilan hidup. Dari empat tujuan utama dikembangkan menjadi delapan program madrasah yang harus dilaksanakan sesuai dengan rencana.

d. Standar Kompetensi Lulusan Madrasah

Standar kompetensi lulusan yang dikembangkan dalam KTSP madrasah tsanawiyah Darul Muttaqin adalah: a) Mampu baca tulis Al-Qur'an, b) Mampu melaksanakan Ibadah Amaliyah sehari-hari, c) Mampu menghafal Juz 'Amma, d) Mampu menyakini dan menjalankan dasar-dasar ajaran Islam, e) Mampu melanjutkan pendidikan ke jenjang yang lebih tinggi, f) Mampu berfikir logis dalam memecahkan masalah, g) mampu berkomunikasi lisan dan tulisan dengan baik dan lancar, h) Mampu bersaing dengan para siswa dari sekolah luar dalam ilmu pengetahuan, i) Memiliki pengetahuan dalam 
ISSN: 1829-6750 Inovasi Kurikulum, Februari 2009, Thn. 6. Vol 6 Nomor: 1

berinteraksi sosial, j) Mampu melaksanakan tugas pribadi secara mandiri, k) Memiliki tanggung jawab dalam melaksanakan tugas pribadi dan sosial, I) Memiliki jiwa kepemimpinan, m) Memiliki keterampilan dalam berbahasa Arab dan Inggris dan $\mathrm{n}$ ) Memiliki jiwa kreatif.

e. Standar Kompetensi Lulusan Madrasah ke dalam standar kompetensi tingkatan (kelas).

Dalam KTSP MTs Darul Muttaqien terdapat empat belas standar kompetensi lulusan MTs Darul Muttaqin dijabarkan menjadi tiga standar kompetensi tingkatan yakni: Kelas 1; Kelas 2; Kelas 3;

\section{Faktor Minimalnya Kapasitas} Guru sebagai Pengembang Kurikulum menjadi Penghambat Pengembangan KTSP MTs Darul Muttaqin

Dari hasil pengembangan KTSP di MTs Darul Muttaqien muncul beberapa persepsi yang disampaikan oleh para pengembang kurikulum, baik yang disampaikan oleh para guru, kepala madrasah, konsultan, pimpinan pondok pesantren, komite dan siswa. Para guru sebagian sudah menggunakan form dokumen KTSP, namun mereka tidak mengenal secara utuh KTSP. Hal ini disebabkan mereka tidak pernah mengikuti sosialisasi KTSP yang diselenggarakan oleh Diknas maupun Depag. Sebagian guru hanya menerima informasi penjelasan dari Kepala Madrasah, termasuk rencana pengembangan KTSP pada MTs Darul Muttaqien. Sebenarnya para guru menyambut antusias terhadap rencana KTSP Darul Muttaqien. Hasil penelitian menunjukkan adanya masukan dan saran yang disampaikan oleh para guru.

Dalam mendukung hasil KTSP tersebut para guru berupaya mengembangkan kurikulum yang berlaku di madrasah yang meliputi:

a. Aktivitas guru dalam merencanakan kurikulum

b. Aktivitas guru dalam melaksanakan kurikulum

c. Aktivitas guru dalam menilai kurikulum

\section{E. SIMPULAN}

Secara umum, penulis menemukan adanya harmoni antara penggunaan kurikulum TMI dengan rencana 
ISSN: 1829-6750 Inovasi Kurikulum, Februari 2009, Thn. 6. Vol 6 Nomor: 1

pengembangan KTSP di MTs Darul Muttaqin, karena kurikulum TMI disinyalir mempunyai kesamaankesamaan dengan KTSP. Hal tersebut dapat dilihat dalam beberapa simpulan berikuti ini:

1. Kurikulum Tarbiyatul Mu'allimin wal Mu'allimat al-Islamiyyah (TMI) MTs Darul Muttaqin adalah kurikulum berkelanjutan antartingkatan MTs (kelas 7 sampai dengan kelas 9) dan MA (kelas 10 sampai dengan kelas 12).

2. Dalam rangka merespons kebijakan implementasi KTSP, MTs Darul Muttaqien telah merumuskan draft KTSP yang akan dibahas oleh forum pengembangan kurikulum internal yang melibatkan komite sekolah/madrasah, orang tua/wali, para guru, kepala sekolah, pengurus pesantren, dan ahli pendidikan (konsultan).

3. Proses pengembangan KTSP pada MTs Darul Muttaqien meliputi beberapa komponen kurikulum, antara lain visi, misi, tujuan, struktur dan muatan kurikulum.

Para pengembang kurikulum MTs Darul Muttaqin pada umumnya telah tertarik untuk mengembangkan KTSP sejak model kurikulum tersebut dikenalkan tahun 2006 yang lalu.

\section{Daftar Pustaka}

Direktorart Jendral Kelembagaan Agama Islam. (2004). Standar Kompetensi Pendidikan Agama Islam Pada Sekolah Umum dan Madrasah. Jakarta : Departemen Agama RI.

Mulyasa, E. (2006). Kurikulum Tingkat Satuan Pendidikan Sebuah Panduan Praktis. Bandung : Rosdakarya

Syaodih Sukmadinata, N.. (2002).Pengembangan Kurikulum Teori dan Praktek. Bandung : Rosdakarya

(2004). Landasan

Psikologi Proses Pendidikan.

Bandung : Rosdakarya

Nasution. (1996). Metode Penelitian Naturalistik Kualitatif. Bandung : Tarsito

Hamalik, O. (2006). Manajemen Pengembangan Kurikulum. Bandung : Rosdakarya 
ISSN: 1829-6750 Inovasi Kurikulum, Februari 2009, Thn. 6. Vol 6 Nomor: 1

Hamid Hasan, S. (1988). Evaluasi Kurikulum. Jakarta : Dirjen Dikti Proyek Pengembangan lembaga Pendidikan Tenaga Kependidika.

Sumantri, M. (2002). Pengembangan Potensi Siswa Dengan Kurikulum Terpadu Untuk Menjadi Manusia Indonesia Seutuhnya. Pidato Pengukuhan jabatan Guru Besar Tetap dalam bidang IImu Perencanaan Kurikulum pada FIPUPI, Bandung.

Uzer. (1992). Menjadi Guru Profesional. Bandung : Rosdakarya

Widodo. ( 1994). Pengembangan Kurikulum dan bahan Belajar II. Jakarta : Universitas Terbuka

Wina Sanjaya. (2007). Strategi Pembelajaran Berorientasi Standar Proses Pendidikan. Jakarta : Kencana Prenada Media Group 